\title{
Reconstruction of Oceanographic Changes Based on the Diatom Records of the Central Okhotsk Sea over the last 500000 Years
}

\author{
Wei-Lung Wang ${ }^{1, *}$ and Liang-Chi Wang ${ }^{1,2}$ \\ ${ }^{1}$ Department of Biology, National Changhua University of Education, Changhua, Taiwan, ROC \\ ${ }^{2}$ Institute of Ecology and Evolutionary Biology, National Taiwan University, Taipei, Taiwan, ROC
}

Received 30 September 2006, accepted 21 September 2007

\begin{abstract}
This study provides insight into changes in sea ice conditions and the oceanographic environment over the past $500 \mathrm{kyr}$ through analysis of the diatom record. Based on the relative abundance of 13 diatoms species in piston core MD012414, four types of environmental conditions in the central Okhotsk Sea over the last $330 \mathrm{ka}$ BP have been distinguished: (1) open-ocean alternating with seasonal sea-ice cover in Stages 9, 5, and 1; (2) almost open-ocean free of sea-ice cover in Stages 7 and 3; (3) perennial sea-ice cover in Stages 6, 4, and 2; and (4) a warm ice-age dominated by open ocean assemblages in Stage 8. The littoral diatom species, Paralia sulcata, showed a sudden increase from the glacial period to the interglacial period over the last $330 \mathrm{ka}$ BP, except during Stage 8. Such a result implies that melting sea-ice transported terrigenous materials from the north Okhotsk Sea continental shelves to the central ocean during deglaciation. From Stage 13 to Stage 10, however, cold and warm marine conditions unexpectedly occurred in the late interglacial periods and the glacial periods, respectively. One possible reason for this is a lack of age control points from Stage 13 to Stage 10, and the different sediment accumulation rates between glacial and interglacial periods. This study suggests not only the process by which oceanographic variation of sea ice occurred, but also new significance for Paralia sulcata as an indicator in the diatom record of the Okhotsk Sea.
\end{abstract}

Key words: Diatom indicator, Okhotsk Sea, Sea-ice, Paleoenvironment

Citation: Wang, W. L. and L. C. Wang, 2008: Reconstruction of oceanographic changes based on the diatom records of the central Okhotsk Sea over the last 500000 years. Terr. Atmos. Ocean. Sci., 19, 403-411, doi: 10.3319/TAO.2008.19.4.403(IMAGES)

\section{INTRODUCTION}

The Okhotsk Sea is part of the Western Pacific Ocean. It plays a significant role in climatic and ocean environmental changes on both a regional and global scale. The Okhotsk Gyre is a component of the Subarctical Gyre, which has a counterclockwise surface flow. The ocean absorbs warmth from the northwest and returns to the southeast, close to the West Kamchatka coast. The main currents in the region such as the West Kamchatkan current (WKC) to the east and the East Sakhalin current (ESC) to the west, along with others, generate a general cyclonic water movement (Stepanov 1974).

The Okhotsk Sea represents both the lowest-latitude and largest region with seasonal sea-ice in the world. Interannual variation in the maximum extent of seasonal sea-ice cover depends on ice advection by wind and air temperature conditions (Kimura and Wakatsuchi 1999). At present, Okhotsk

* Corresponding author

E-mail:wlwang@cc.ncue.edu.tw sea ice forms in the northwestern coastal area in November (Wakabayashi et al. 1995). Its maximum elongation extends as far south as northern Hokkaido in March and disappears by June (Shimada and Hasegawa 2001).

Intermediate seawater from the Okhotsk Sea is a possible source of North Pacific Intermediate Water. The formation of Okhotsk Sea Intermediate Water (OIW) during the summer is perhaps associated with the inflow of saline water of the Tsushima Current from the Japan Sea through the Soya Strait. Okhotsk Sea Intermediate Water is formed largely through sinking of brine water, which the sea-ice rejects, along the northwest shelf of the Okhotsk Sea (Wong et al. 1998). A portion of the NPIW is formed in the Okhotsk Sea and flows out mainly through the Bussols' Strait into the North Pacific (Talley 1991; Freeland et al. 1998).

Ternois et al. (2000) reconstructed paleotemperature changes over the last $15 \mathrm{ka}$ for the southern Okhotsk Sea based on alkenones. Organic geochemical and terrestrial 
biomarkers were studied in the sediments from the last $27 \mathrm{ka}$ for the Okhotsk Sea (Ternois et al. 2001). They suggested that sea-ice rafting was the main transport mechanism by which continental material became Okhotsk Sea sediments during the glacial to early interglacial periods. Paleohydrographic profiles below a depth of $1000 \mathrm{~m}$ were reconstructed employing stable isotope data on benthic foraminifera (Gorbarenko 1996; Keigwin 1998; Gorbarenko et al. 2002, 2004).

In this study, we utilize the relative abundance of sea-ice, high-productivity and open-ocean diatom assemblages to reconstruct sea ice conditions in the Okhotsk Sea over the last $500 \mathrm{ka}$. Three sets of sea-ice conditions and their corresponding diatom assemblages are defined: (1) perennial sea-ice cover is characterized by increases in sea-ice assemblages and lower amounts of diatom valves. Such a scenario describes eternal sea ice cover where only rare amounts of sea-ice diatom survive in the ice sheet; and the ice lid prevents not only diatoms but also other possible sources of biotic and abiotic material settlement that might be carried on currents or in the atmosphere. This barren phenomenon has been discussed not only in the context of diatoms (Shiga and Koizumi 2000; Koizumi et al. 2003) but also radiolarian (Matul et al. 2003; Okazaki et al. 2003); (2) open-ocean conditions free of sea ice are characterized by the dominance of open-ocean assemblages (Barash et al. 2001, 2005, 2006). In this scenario, the warm current from the north Pacific gyre frees the Okhotsk Sea of sea ice and brings with oceanic assemblages; (3) seasonal sea ice conditions are characterized by a lower proportion of sea-ice assemblages and a higher proportion of high-productivity assemblages. It is quite likely that ice floe, accompanied by cold low-salinity surface water from melted ice, suppressed total diatom production and increased sea-ice assemblages (Smith and Nelson 1985; Wilson et al. 1986; Shimada and Hasegawa 2001).

To explore possible scenarios of oceanic evolution, especially NPIW and sea ice succession, the international IMAGES VII circum-Pacific initiative (WEPAMA) conducted deep sediment-core drilling work in the central Okhotsk Ocean and successfully cored a long (ca. $53.88 \mathrm{~m}$ ), high resolution core (MD012414), reflecting 1.8 Myrs of climate history (Lui et al. 2006).

We adopt the diatom for its robustness as a proxy to help reveal environmental fluctuations including sea ice variations and NEIW evolution throughout the last $500 \mathrm{ka} \mathrm{BP}$ in the Okhotsk Sea.The aim of this study, however, is not only to reconstruct a possible pattern of the past climate, but also to seek out other potential robust diatom indictors in this area.

\section{MATERIAL AND METHODS}

Figure 1 shows sediment core MD012414 retrieved from the center of the Okhotsk Sea during IMAGES VII cruise in 2001. The coring site for MD012414 is located near the mixing zone of the southward-flowing East Sakhalin Current (ESC). This zone consists of fresh-water discharged from the Amur River, and the salty Soya Warm Current originating in the Tsushima Warm Current in the Japan Sea. It has been suggested that the growth of sea-ice in the area leads to the formation of dense, saline shelf waters during the winter periods, while intermediate water formation during the summer periods might be associated with the salty Soya Warm Current (Watanabe and Wakatsuchi 1998).

In order to reconstruct what changes might have occurred in the oceanographic environment of the Okhotsk Sea, paleoceanographic analyses based on the distribution of the 13 characteristic diatom species proposed by Shiga and Koizumi (2000) and Koizumi et al. (2003), and their abundance (valves $\mathrm{g}^{-1}$ dry weight) were carried out.

For quantitative analysis, one gram of dry sediment was subsampled and chemically treated to clean and concentrate the diatoms. The calcium carbonate component was removed by adding concentrated $\mathrm{HCl}(10 \%)$, and the organic matter was oxidized using hydrogen peroxide $\left(\mathrm{H}_{2} \mathrm{O}_{2} 30 \%\right)$. Fractions were diluted in $20 \mathrm{ml}$ of distilled water pipetted onto a glass slide, using Pleurax as the mounting medium. Light-microscope observations were made at magnifications of $1000 \mathrm{x}$, at least 400 valves were counted per sample, and specific frequencies were computed.

The previous study in this core (Lui et al. 2006) utilized

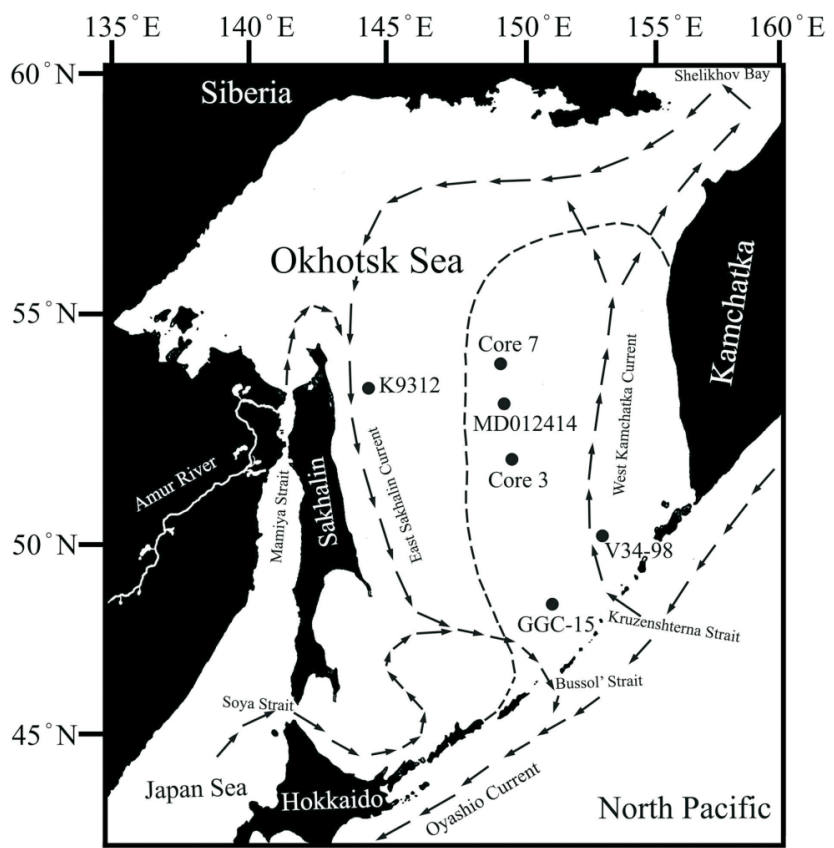

Fig. 1. Locations of MD012414 and other relative cores in the Okhotsk Sea. Arrows indicate flow of ocean surface currents in the Okhotsk Sea and surrounding areas. The present location of sea-ice from March to April is represented by a dotted line (After Koizumi et al. 2003). 
color $b^{*}$ analogous to MD012414 and MD012415, and built a reliable age model up. In this study, we also adopt this age model.

\section{RESULTS}

\subsection{Distribution of the 13 Characteristic Diatom Species}

There are 87 diatom taxa examined in the upper $20 \mathrm{~m}$ of core MD012414. Most of them are typical of present day Okhotsk, being widespread in the sediment (Sancetta 1982). However, we only adopt the 13 selected taxa in this study because of the clear environmental significance attributed to these species in previous research (Shiga and Koizumi 2000; Koizumi et al. 2003) into the Okhotsk Sea. Furthermore, the 13 diatom taxa are constitute more than $80 \%$ of the diatoms in the upper $20 \mathrm{~m}$ of the core and therefore well reflect environmental oceanic change.
Sea-ice assemblages included Bacterosira bathyomphalus, Fragilariopsis cylindra, F. oceanica, Thalassiosira antarctica, and $T$. nordenskioldii. The general pattern of this sea-ice group is that they became rare obviously in the interglacial stage but more evident in the glacial stage (Fig. 2). However, in Stage 8, only low amounts of sea-ice assemblages are evident and only Thalassiosira antarctica shows a slight increased. Some other cold events revealed by abnormal pulses in sea-ice assemblages (Fig. 3) during the warm period are worth examining in: late Stage 13, early Stage 11, early Stage 7, and early Stage 1 .

High-productivity assemblages consisted of Neodenticula seminae, Thalassiosira latimaginata, and Thalassiothrix longissima. These assemblages displayed similar patterns to those of diatom abundance showing two peaks in early Stage 9, and one peak in late Stage 5 and early Stages 13, 11, and 1 (Fig. 3). Thalassiosira latimaginata is do-

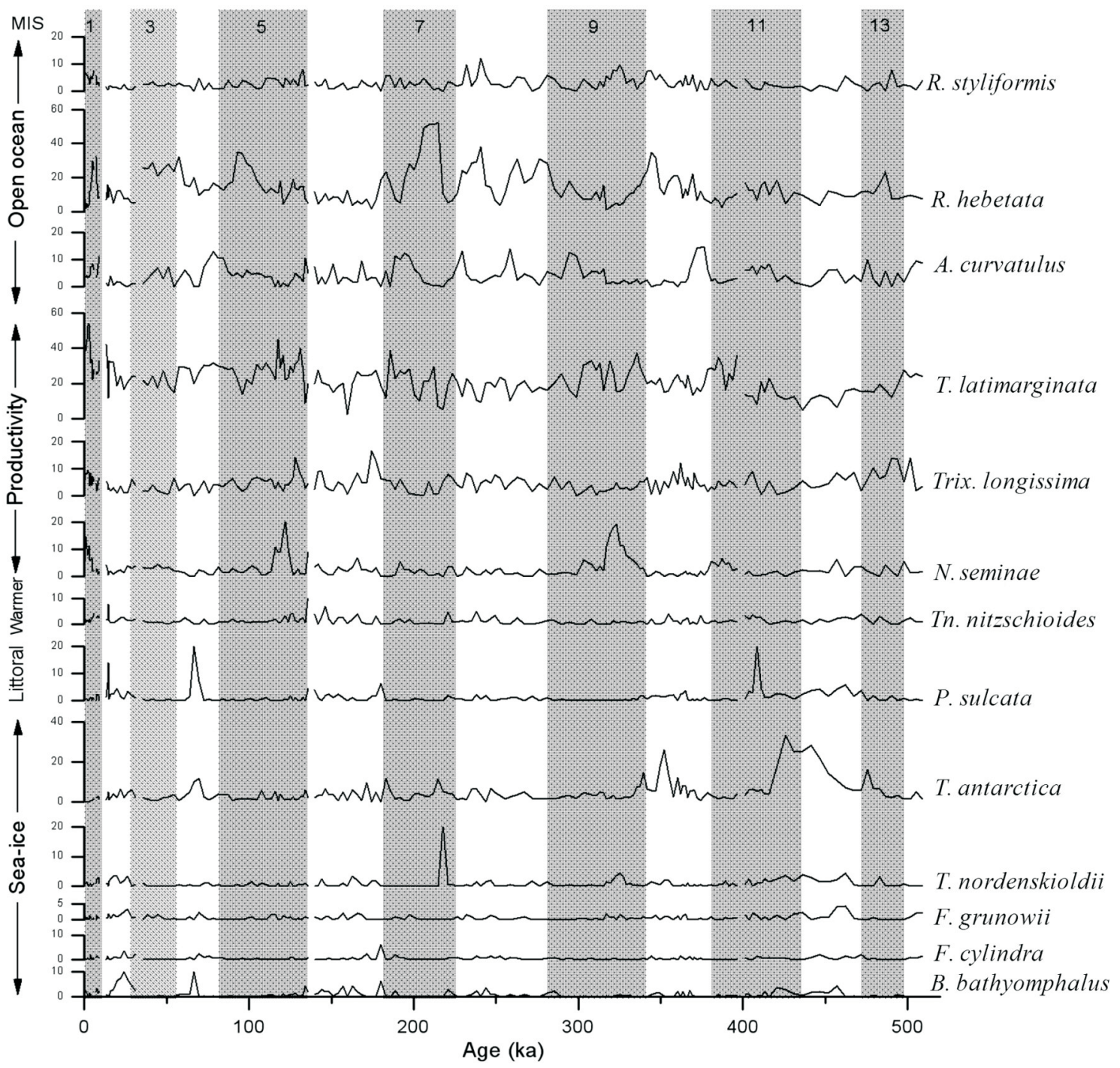

Fig. 2. Chronology of relative abundance (\%) of 13 characteristic diatom species belonging to five different assemblages in core MD012414. 


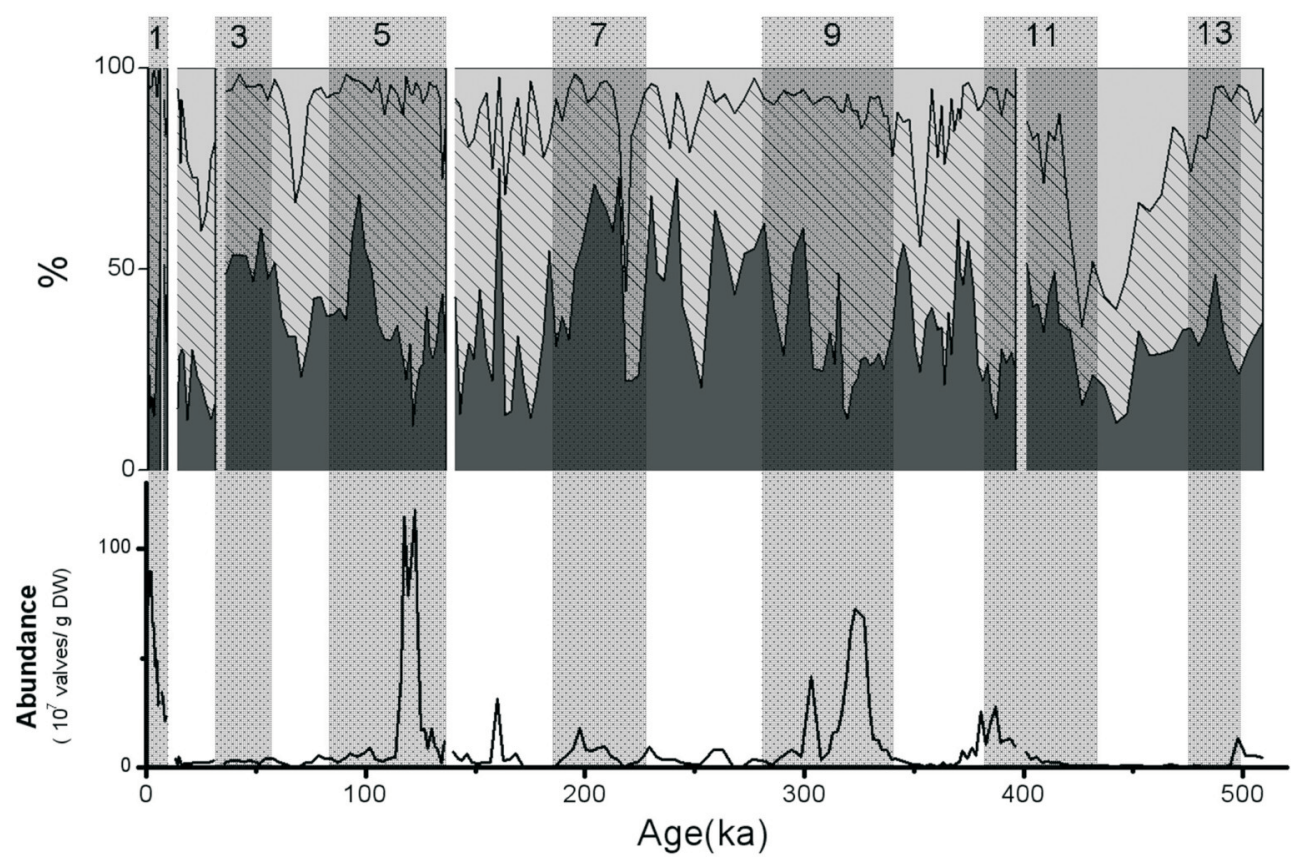

Fig. 3. Chronology of sea-ice (gray), high productivity (striated) and open-ocean (black) assemblages and diatom abundance in core MD012414. The existence of both dominant high productivity assemblages and large amounts of diatom valves indicates seasonal sea ice cover. Dominant open-ocean and sea-ice assemblages refer to ice-free and eternal sea-ice cover scenarios, respectively.

minant with Thalassiothrix longissima having a minor presence. Anomalous increases of $N$. seminae occurred in early and late Stage 6 (Fig. 2).

Open-ocean species included Rhizosolenia hebetata, Rhizosolenia styliformis, and Actinocyclus curvatulus. Rhizosolenia hebetata is dominant with Rhizosolenia styliformis having a minor presence. Open-ocean assemblages contributed much less in the cold stages than the warmer ones, but abnormally high abundance phenomena could be found in cold Stages 10 and 8 (Fig. 3).

The littoral species, Paralia sulcata, was very rare throughout the core, spiking briefly in each deglacial period, except in Stage 8 (Fig. 2).

\subsection{Diatom Abundance (valves $\mathrm{g}^{-1} \mathrm{DW}$ ) in Core MD012414}

The number of diatom valves varied from $0.04 \times 10^{7}$ valves $\mathrm{g}^{-1} \mathrm{DW}$ (dry weight) at $227 \mathrm{ka} \mathrm{BP}$ to $117.8 \times 10^{7}$ valves $\mathrm{g}^{-1} \mathrm{DW}$ at $119 \mathrm{ka} \mathrm{BP}$, the maximum value (Fig. 3). The mean diatom abundance was $12.7 \times 10^{7}$ valves $\mathrm{g}^{-1} \mathrm{DW}$. Across the period of the study, diatom abundance was lower than average in all ice-ages, except for one spike at $155 \mathrm{ka}$ BP. The abundance of diatoms in high-productivity assemblages showed a similar pattern. During warmer periods when high-productivity species were dominant, diatom abundance was almost always above average. However, when open-ocean species predominated or sea-ice species increased, diatom abundance showed clear identifiable decreases falling below average levels.

\section{DISCUSSION}

\subsection{Changes in Sea-Ice Recorded in MD012414}

According to Shiga and Koizumi (2000), sea-ice free waters contracted to the present extent at $7 \mathrm{ka} \mathrm{BP}$, and the location of the sea-ice margin was very similar to that of the present day from March to April. Core MD012414 was taken from a location close to the current mean ice extent from February to April (Fig. 1). Variations in centennial time scales since $7 \mathrm{ka}$ BP can be documented by analyzing diatom assemblages in the western part of the Okhotsk Sea. While small time-scale studies of the LGM and the Holocene have been performed, we still lack large time-scale studies of the glacial-interglacial cycles. This study attempts to reconstruct sea-ice patterns during the glacial and interglacial periods from $500 \mathrm{ka}$ BP to the present, and determine the composition of sea-ice for all seven interglacial and the six glacial periods during this time.

In Stage 13, high productivity assemblages are dominant and alternate with open-ocean assemblages. Moreover, about $450 \mathrm{ka}$ sea ice assemblages increase and rare diatom valves accumulate (Fig 3). This response suggests that open-ocean conditions consequently change to perennial sea-ice cover in Stage 12. All three types of sea ice conditions are evident in Stage 11. They are sequentially perennial sea-ice, ice-free and seasonal sea-ice cover, and company with the gradually increased abundance. A quite different scenario is found out in Stage 10. During this stage, perennial sea-ice is formed during the middle period but the environment abruptly changes back to open ocean conditions. 
This phenomenon may infer a relatively warmer climate or more input from the North Pacific current.

In Stage 9, high productivity assemblages are dominant and diatom abundance is always above average, with the exception of a period $310 \mathrm{ka} \mathrm{BP}$, when the open-ocean assemblages show an increase with large fluctuations. Two short open ocean events between 300 - 340 ka were examined in recent research on the central Okhotsk Sea (Barash et al. 2006). Four cooling events were evidenced by corresponding increases in sea-ice assemblages and smaller numbers of diatom valves. In Stage 6, the ocean is almost entirely covered by ice, as identified by extremely rare amounts of diatoms and increased sea-ice assemblages. Four peaks in open-ocean assemblages indicate ice-free open ocean.

In early Stage 5, between 129 and $107 \mathrm{ka} \mathrm{BP}$, a high proportion of high-productivity assemblages and a great increase in diatom abundance indicate seasonal sea-ice conditions. From 107 to $73 \mathrm{ka}$ BP, the open-ocean assemblages become abundant, suggesting that seasonal sea-ice gave way to ice-free conditions.

A relatively high proportion of sea-ice assemblages and lower productivity and oceanic assemblages, along with smaller numbers of diatom valves, suggest that the area has perennial ice-cover in Stages 4 and 2. Throughout Stage 3, both the sea-ice and high-productivity assemblages are found in lower proportions, while the open-ocean assemblage becomes abundant, indicating ice-free conditions.

In early Stage 1, from 9 to $7 \mathrm{ka} \mathrm{BP}$, sea-ice assemblages continually decrease, while the proportion of open-ocean assemblages rises, indicating ice-free conditions. From $6 \mathrm{ka}$ $\mathrm{BP}$ on, a high proportion of high-productivity assemblages and increasing numbers of diatom valves indicate seasonal sea-ice.

\subsection{Comparing the Climate of Different Stages}

The climate history of the Okhotsk Sea for the past $500 \mathrm{ka}$ was reconstructed based on sea ice conditions. Open-ocean conditions indicate a warm climate, while seasonal or perennial sea ice is attributed to both cool and cold climates (Koizumi et al. 2003). According to this hypothesis, high diatom-abundant stages, i.e., Stages 13, 11, 9, 5, and 1 , have relative warm climates that alternate with cold events. The warmer stages, indicated by having a high proportion of open-ocean assemblages, are Stages 7 and 3.

Among the glacial periods, Stage 12 exhibits the coldest conditions throughout the $500 \mathrm{ka}$. During the other ice ages, the study area was perennially ice-covered, but some warm events did occur. Stage 8 was a very warm ice age, quite distinct from the other glacial periods. In support of our observations, this anomalous stage was previously examined by Barash et al. (2006) and Lui et al. (2006). In addition, previously determined alkenone-SST in the PC2 (Seki et al. $2004 a, b)$ suggest a warm event in Stage 5 a and a cold period in early Stage 3; both these events are recognized in this study.

\subsection{The NIPW Supply from the Okhotsk Sea}

The NPIW, defined as the salinity minimum at depth $300-500 \mathrm{~m}$, is formed somewhere in the northwestern (NW) Pacific. Its source has been identified as the Okhotsk Sea (Yasuda 1997). Okhotsk intermediate water is produced by brine rejection during the formation of the sea ice on the continental shelf in winter. It is exported by vertical change in the Bussols' Strait to ventilate the subpolar gyre of the North Pacific Ocean. Okhotsk Sea seasonal sea ice formation is the key process driving NPIW production at present.

Pacific intermediate circulation may have changed significantly during glacial periods. The ventilation of the intermediate water from glacial higher oxygen conditions to Holocene low oxygen conditions has been observed in the Santa Barbara Basin, in the northeastern (NP) Pacific (Kennett and Ingram 1995; Behl and Kennett 1996), and better ventilation has been found at depths shallower than $2 \mathrm{~km}$ in the glacial Okhotsk Sea of the NW Pacific (Keigwin 1998).

The glacial distribution of the NPIW radiolarian indicator, Cycladophora davisiana, dominates in the North Pacific and the Bering Sea, but is barren in the Okhotsk Sea (Okazaki et al. 2003), which suggests that the intermediate water is derived from the Bering Sea rather than the Okhotsk Sea (Ohkushi et al. 2003). During LGM, the sea ice cover is heavy and there is no formation of winter sea ice in the shelf region where the intermediate water is currently produced. This suggests that the existence of seasonal sea ice is the key condition for NPIW supply from the Okhotsk Sea. On the basis of the correlation between the NPIW and sea ice conditions, we suggest that NPIW products in the Okhotsk Sea increase in volume during periods of seasonal sea ice cover, rather than during periods of perennial sea ice cover. By the same token, periods of open ocean in the study area indicate a more limited southern extension of winter sea ice, which indicates that the NPIW supply probably mediates all three types of sea ice conditions.

\subsection{Paralia sulcata as An Indicator of Continental Detritus Input in the Okhotsk Sea}

Paralia sulcata (Ehrenberg) Cleve is a brackish to marine diatom found in benthic microphyte communities in temperate coastal waters. The thick walls of $P$. sulcata sink readily and are relatively resistant to dissolution, and both these factors contribute to its abundance in coastal sediment records. The most common interpretation of $P$. sulcata is as an indicator of coastal upwelling situations which result in high primary production (Abrantes 1988a, b, 1991). Paralia sulcata does not typically form large blooms in plankton, but high proportions can be found in the water column during 
winter (Sancetta 1989; Hobson and McQuoid 1997). Since $P$. sulcata grows primarily in benthic habitats, physical forces such as strong winds (Haggart 1988; Cullingford et al. 1989) and tidal mixing (Oh and Koh 1995) may be primary mechanisms for the transport of cells into the plankton. The diameter of $P$. sulcata usually ranges between 8 and $29 \mu \mathrm{m}$. However, cells up to $130 \mu \mathrm{m}$ have been recorded (Hasle and Syvertsen 1996). There is growing evidence that environmental conditions can regulate changes in valve diameter. Small cells are more numerous in highly productive waters (Roelofs 1984), and larger valve diameters are most abundant in moderately low salinities (Sherrod 1999) or when nutrient availability is patchy (Abrantes 1988a). In this study, the valves of $P$. sulcata are almost all small, suggesting high productivity conditions.

A sudden increase in P. sulcata occurs at the end and beginning of glacial periods, except in Stages 11 and 8 (Fig. 2). Two explanations for this phenomenon have been proposed in this study. In the first, changes in the local physical environment, such as upwellings or nutrient input increases, stimulate $P$. sulcata production. However, there are no reports of upwellings in the central Okhotsk Sea, or periods of nutrient input increases (Ternois et al. 2001). Further, high productivity periods, indicated by diatom records, are not concurrent with $P$. sulcata increases. Alternatively, P. sulcata may be reworking species transported from other places. Where is the possible source of $P$. sulcata in the Okhotsk Sea? According to satellite remote sensing data (SeawiFS 1986), the north shelf area exhibits upwelling and has the highest productivity in the Okhotsk Sea (Nezlin et al. 1997; Nimmergut and Abelmann 2002). In the sediment record, P. sulcata is also dominant in this area (Sancetta 1982). This data suggests that the continental shelf is the likely source of $P$. sulcata.

Atmospheric circulation, fluvial input, and sea-ice constantly erode the north continental shelves and transport the reworking $P$. sulcata to the central Okhotsk Sea. The atmospheric transport of materials to the marginal sediments is a key process, and enhanced terrigenous inputs in the glacial period has been observed from the Equatorial Pacific (Ohkouchi et al. 1997a, b), the Northwest Pacific (Gorbarenko 1996), and the Japan Sea (Ishiwatari et al. 1994). Those have been explained by an enhancement of atmospheric circulation, eolian dust transport, or the dust scavenging rate. However, the enhancement of atmospheric circulation during glacial periods is continual, and this mechanism can hardly explain the drastic increase of continental supply in the short intervals. Dust transport by atmospheric circulation accumulates in the glacial periods, when the sea is perennially ice-covered. The dust sinks to the bottom sediments when the ocean condition changes to seasonal ice cover or ice free, and the perennial sea-ice melts. However, intervals of sea-ice melting are not simultaneous with $P$. sulcata increase events.
Fluvial inputs, mostly from the Amur River, and detrital inputs from continental shelf erosion are two important processes for the transport of continental materials to the marginal ocean. However, the former mechanism can hardly explain the drastic increase in continental supply observed in the Okhotsk Sea during the glacial period, since much dryer conditions, which probably prevailed over the Asian continent at that time (Hovan et al. 1991), would have reduced the water inflow from the Amur River to the Okhotsk Sea.

Several lines of evidence suggest that continental shelf erosion caused by sea-level rise has occurred in the North Pacific Ocean. Increased shelf weathering associated with sea-ice transport of the eroded material has been proposed to intensify continental detrital accumulation in glacial sediments (Conolly and Ewing 1970; Keigwin et al. 1992). During such periods, strong winter storm and moderate summer conditions enhance the generation of sea-ice near the coast, which may induce an uptake of eroded continental materials into the bottom of the sea-ice by freezing processes. Enhanced oceanic circulation probably promotes long-distance transport of sea-ice. Then, far from its source region, it melts in the summer, allowing the vertical transport of the sea-ice-entrapped shelf materials to the ocean floor (COHMAP 1988).

Relative abundance of $P$. sulcata in the central area of the Okhotsk Sea (this study) and the terrigenous biomarkers in southern areas, (Ternois et al. 2000) increased simultaneously (Fig. 4), reflecting the vertical transport of the sea-ice-entrapped shelf materials to the ocean floor. The results indicate that enhanced erosion of the shelves due to sea-level rise, coupled with ice rafting processes, is the mechanism responsible for the supply of a significant amount of continental materials to the Okhotsk Sea sedi-

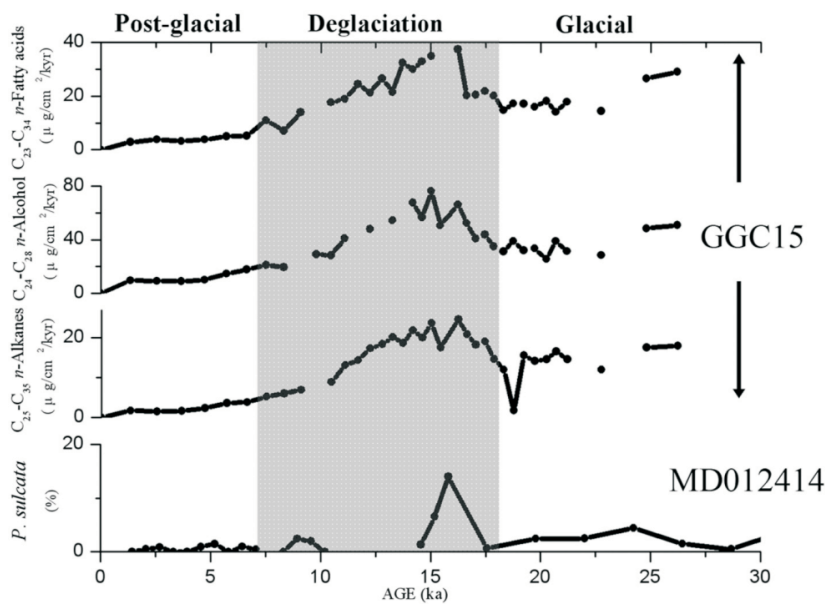

Fig. 4. Downcore profiles of the terrigenous biomarker accumulation rate $\left[\left(\right.\right.$ in $\left.\left.\mu \mathrm{g} \mathrm{cm}^{-2}\right) \mathrm{kyr}^{-1}\right]$ and Paralia sulcata relative abundance $(\%)$ in the south (GGC15, after Ternois et al. 2001) and central (MD012414, this study) Okhotsk sediment cores, respectively. The shaded area represents the deglaciation periods. 
ments (Ternois et al. 2001). That there was no P. sulcata increase event in Stage 8, the ice-free glacial period, also suggests that this event was sea-ice-dependent. Moreover, the abnormal pulse in sea-ice assemblages in $410 \mathrm{ka}$ also indicates a heavy sea-ice cover scenario (Fig. 3), and the phase lag for the ice melting should be a reliable cause.

Comparison of levels of P. sulcata in MD012414 and four other cores from the Okhotsk Sea at the $20 \mathrm{ka}$ mark (Table 1), shows that sudden increase events of $P$. sulcata have been observed not only in MD012414, but in two other cores, cores 7 and 3, in the central area (Fig. 5, Shiga and Koizumi 2000). Sea-ice transport has been observed in four cores (cores 7, 3, MD012414, and GGC15), and $P$. sulcata and terrigenous biomarkers are found in cores from the center and south Okhotsk Sea, respectively. However, $P$. sulcata is rare in the cores from offshore Kamachata (V34-98) and Sakhalin (K9312). The distribution of those cores implies sea rafting transport from the north continental shelf to the south basin, though limited in the Okhotsk Gyre.

\section{CONCLUSIONS}

This fossil diatom study of central Okhotsk Sea sediment core MD012414 enables us to reconstruct sea ice conditions over the past $500 \mathrm{ka}$. The existence of alternating high proportion high-productivity and open-ocean assemblages indicates alternating cold and warm climates in Stages 9, 5, and 1. The dominance of open-ocean assemblages indicates a warm climate in Stages 7 and 3. In the glacial periods, Stages 6,4 , and 2, have very cold climates described by sudden increases in littoral diatoms transported by melting sea-ice from the northeast reefs in the colder stages. Littoral species, P. sulcata, and the terrigenous biomarker share a variation peak in continental supply at $15 \mathrm{ka}$ BP. This sudden increase in ice-rafted detrital materials may involve materials from the continental shelves of the northern Okhotsk Sea. Melting of perennial sea-ice cover and changes in the sea-level are the primary forces responsible for eroding the northern reefs of the Okhotsk Sea during the deglacial periods, resulting in the transport of not only terrigenous materials, but reworked littoral diatoms present in the littoral sediments.

Acknowledgements We thank the members of core repository and laboratory, the National Center for Ocean Research (NCOR), Keelung for sampling assistance and the members of the IMAGES group of Taiwan for providing us with great encouragement and many useful discussions. We would also like to thank Michael Turton of Chaoyang University, Taiwan for his help in reading this manuscript. This work was supported by National Science Council grant NSC 91-2611-M-018-001-IM.

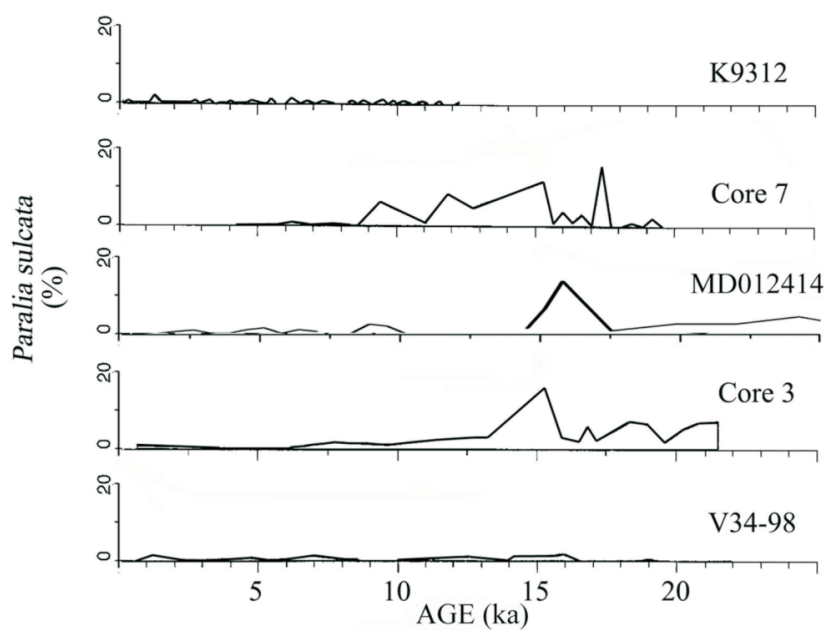

Fig. 5. Downcore profiles of Paralia sulcata relative abundance in different locations, K9312, Core 7, 3, V34-98 (after Shiga and Koizumi 2000) and MD012414 (this study), in the Okhotsk Sea. A Paralia sulcata sudden increase event happened simultaneously in the central Okhotsk Sea about $15 \mathrm{ka}$

Table 1. Core information of MD012414 and relative cores collected from the Okhotsk Sea.

\begin{tabular}{|c|c|c|c|c|c|c|}
\hline Core ID & Latitude & Longitude & Water depth (m) & Core lengh (cm) & Bottom age (ka) & Reference \\
\hline \multicolumn{7}{|l|}{ Diatom } \\
\hline MD012414 & $53^{\circ} 11^{\prime} \mathrm{N}$ & $149^{\circ} 34^{\prime} \mathrm{E}$ & 1123 & 5388 & 1771.4 & This study \\
\hline V34-98 & $50^{\circ} 07^{\prime} \mathrm{N}$ & $153^{\circ} 12^{\prime} \mathrm{E}$ & 1175 & 330 & 19.8 & Shiga and Koizumi 2000 \\
\hline core 3 & $15^{\circ} 57^{\prime} \mathrm{N}$ & $149^{\circ} 48^{\prime} \mathrm{E}$ & 974 & 97 & 21.5 & Shiga and Koizumi 2000 \\
\hline core 7 & $53^{\circ} 59^{\prime} \mathrm{N}$ & $149^{\circ} 13^{\prime} \mathrm{E}$ & 910 & 113 & 19.6 & Shiga and Koizumi 2000 \\
\hline K9312 & $53^{\circ} 32^{\prime} \mathrm{N}$ & $144^{\circ} 03^{\prime} \mathrm{E}$ & 1005 & 687 & 12.4 & Shiga and Koizumi 2000 \\
\hline \multicolumn{7}{|l|}{ Biomarker } \\
\hline GGC-15 & $48^{\circ} 10^{\prime} \mathrm{N}$ & $151^{\circ} 20^{\prime} \mathrm{E}$ & 1980 & 325 & 26.2 & Ternois et al. 2001 \\
\hline
\end{tabular}




\section{REFERENCES}

Abrantes, F., 1988a: Diatom productivity peak and increased circulation during latest Quaternary: Alborian Basin western Mediterranean. Mar. Micropaleontol., 13, 79-96.

Abrantes, F., 1988b: Diatom assemblages as upwelling indicators in surface sediments off Portugal. Mar. Geol., 85, 15-39.

Abrantes, F., 1991: Increased upwelling off Portugal during the last glaciation: Diatom evidence. Mar. Micropaleontol., 17, 285-310.

Barash, M. S., N. V. Bubenshchikova, G. Kh. Kazarina, and T. A. Khusid, 2001: Paleoceanography of the central part of the Sea of Okhotsk over the past 200 ky. Oceanology, 41, 723-735.

Barash, M. S., M. P. Chekhovskaya, and N. Bibo, 2005: On the Quaternary paleoceanology of the southeastern Part of the Sea of Okhotsk from lithology and planktonic foraminifera. Oceanology, 45, 257-268.

Barash, M. S., A. G. Matul, G. Kh. Kazarina, T. A. Khusid, A. Abelmann, N. Biebow, D. Nürnberg, and R. Tiedemann, 2006: Paleoceanography of the central Sea of Okhotsk during the Middle Pleistocene (305-190 ka) as inferred from micropaleontological data. Oceanology, 46, 537549.

Behl, R. J. and J. P. Kennett, 1996: Brief interstadial events in the Santa Barbara basin, NE Pacific, during the past $60 \mathrm{ka}$. Nature, 379, 243-246.

COHMAP members, 1988: Climatic changes of the last 18,000 years: Observations and model simulations. Science, 241, 1043-1052.

Conolly, J. and M. Ewing, 1970: Ice-rafted detritus in Northwest Pacific deep-sea sediments. Geol. Soc. Am. Bull., 126, 219-231.

Cullingford, R. A., C. J. Caseldine, and P. E. Gotts, 1989: Evidence of early Flandrian tidal surges in Lower Strathearn, Scotland. J. Quat. Sci., 4, 41-60.

Freeland, H. J., A. S. Bychkov, F. Whitney, C. Taylor, C. S. Wong, and G. I. Yurasov, 1998: WOCE section P1W in the Sea of Okhotsk 1. Oceanographic data description. $J$. Geophys. Res., 103, 15613-15623.

Gorbarenko, S. A., 1996: Stable isotope and lithologic evidence of late-glacial and Holocene oceanography of the northwestern Pacific and its marginal seas. Quat. Res., 46, 230-250.

Gorbarenko, S. A., T. A. Khusid, I. A. Basov, T. Oba, J. R. Southon, and I. Koizumi, 2002: Glacial Holocene environment of the southeastern Okhotsk Sea: Evidence from geochemical and paleontological data. Palaeogeogr. Palaeoclimatol. Palaeoecol., 177, 237-263, doi: 10.1016/ S0031-0182(01)00335-2.

Gorbarenko, S. A., J. R. Southon, L. D. Keigwin, M. V. Cherepanova, and I. G. Gvozdeva, 2004: Late Pleistocene - Holocene oceanographic variability in the Okhotsk Sea: Geochemical, lithological and paleontological evidence.
Palaeogeogr. Palaeoclimatol. Palaeoecol., 209, 281-301, doi: 10.1016/j.palaeo.2004.02.013.

Haggart, B. A., 1988: The sratigraphy, depositional enviroment and dating of a possible tidal surge deposit in Beauly Firth area, northwest Scotland. Palaeogeogr. Palaeoclimatol. Palaeoecol., 66, 215-230.

Hasle, G. R. and E. E. Syvertsen, 1996: Marine diatom. In: Tomas, C. R. (Ed.), Identifying Marine Diatoms and Dinoflagellates. San Diego, Academic Press, 5-385.

Hobson, L. A. and M. R. McQuoid, 1997: Temporal variations among planktonic diatom assemblages in a turbulent environment of the southern Strait of Georgia, British Columbia, Canada. Mar. Ecol. Prog. Ser., 150, 263-274.

Hovan, S. A., D. K. Rea, and N. G. Pisias, 1991: Late Pleistocene continental climate and oceanic variability recorded in Northwestern Pacific sediments. Paleoceanography, 6, 349-370.

Ishiwatari, R., Y. Hirakawa, M. Uzaki, K. Yamada, and T. Yada, 1994: Organic geochemistry of the Japan Sea sediments-1: Bulk organic matter and hydrocarbon analyses of core $\mathrm{KH}-79-33, \mathrm{C}-3$ from the Oki ridge for paleoenvironmental assessments. J. Oceanogr., 50, 179-195.

Keigwin, L. D., G. A. Jones, and P. N. Froehlich, 1992: A 15,000 year paleoenvironmental record from Meiji Seamount, far northwestern Pacific. Earth Planet. Sci. Lett., 111, 425-440.

Keigwin, L. D., 1998: Glacial-age hydrography of the far northwest Pacific. Paleoceanography, 13, 323-339.

Kennett, J. P. and B. L. Ingram, 1995: A 20,000-year record of ocean circulation and climate change from the Santa Barbara basin. Nature, 377, 510-513.

Kimura, N. and M. Wakatsuchi, 1999: Processes controlling the advance and retreat of sea ice in the Sea of Okhotsk. $J$. Geophys. Res., 104, 11137-11150, doi: 10.1029/1999JC 900004.

Koizumi, I., K. Shiga, T. Irino, and M. Ikehara, 2003: Diatom record of the late Holocene in the Okhotsk Sea. Mar. Micropaleontol., 49, 139-156, doi: 10.1016/S0377-8398 (03)00033-1.

Lui, Y. J., S. R. Song, T. Q. Lee, M. Y. Lee, Y. L. Chen, and H. F. Chen, 2006: Mineralogical and geochemical changes in the sediments of the Okhotsk Sea during deglacial periods in the past 500 kyrs. Global Planet. Change, 53, 47-57, doi: 10.1016/j.gloplacha.2006.01.007.

Matul, A. G., S. A. Gorbarenko, V. V. Mukhina, and V. Y. Leskov, 2003: The Quaternary micropaleontological and lithophysical records in the sediments of the northern part of the Sea of Okhotsk. Oceanology, 43, 551-560.

Nezlin, N. P., E. I. Musaeva, and V. Y. Dyakonov, 1997: Estimation of plankton stocks in the western part of the Sea of Okhotsk. Oceanology, 37, 408-413.

Nimmergut, A. and A. Abelmann, 2002: Spatial and seasonal changes of radiolarian standing stocks in the Sea of Okhotsk. Deep-Sea Res. I, 49, 463-493, doi: 10.1016/ S0967-0637(01)00074-7. 
Oh, S. H. and C. H. Koh, 1995: Distribution of diatoms in the surficial sediments of the Mangyung-Dongjin tidal flat, west coast of Korea (Eastern Yellow Sea). Mar. Biol., 122, 487-496.

Ohkouchi, N., K. Kawamura, and A. Taira, 1997a: Fluctuations of terrestrial and marine biomarkers in the Western tropical Pacific during the last 23,300 years. Paleoceanography, 12, 623-630.

Ohkouchi, N., K. Kawamura, and A. Taira, 1997b: Molecular paleoclimatology: Reconstruction of climate variabilities in the late Quaternary. Org. Geochem., 27, 173-183.

Ohkushi, K., T. Itaki, and N. Nemoto, 2003: Last GlacialHolocene change in intermediate-water ventilation in the Northwestern Pacific. Quat. Sci. Rev., 22, 1477-1484, doi: 10.1016/S0277-3791(03)00082-9.

Okazaki, Y., K. Takahashi, H. Yoshitani, T. Nakatsuka, M. Ikehara, and M. Wakatsuchi, 2003: Radiolarians under the seasonal sea-ice cover conditions in the Okhotsk Sea: Flux and their implications for paleoceanography. Mar. Micropaleontol., 49, 195-230, doi: 10.1016/S0377-8398(03) 00037-9.

Roelofs, A. K., 1984: Distributional patterns and variation of valve diameter of Paralia sulcata in surface sediments of sediments of southern British Columbia Inlets. Estuar. Coast. Shelf Sci., 18, 165-176.

Sancetta, C., 1982: Distribution of diatom species in surface sediments of the Bering and Okhotsk seas. Micropaleontology, 28, 221-257.

Sancetta, C., 1989: Spatial and temporal trends of diatom flux in British Columbia fjords. J. Plankton Res., 11, 503-520.

SeawiFS Project, 1986: Chlorophyll pigment concentration. http://seawifs.gsfc.nasa.gov.

Seki, O., M. XIkehara, K. Kawamura, T. Nakatsuka, K. Ohnishi, M. Wakatsuchi, H. Narita, and T. Sakamoto, 2004a: Reconstruction of paleoproductivity in the Sea of Okhotsk over the last 30 kyr. Paleoceanography, 19, 1016, doi: 10.1029/2002PA000808.

Seki, O., K. Kawamura, M. Ikehara, T. Nakatsuka, and T. Oba, 2004b: Variation of alkenone sea surface temperature in the Sea of Okhotsk over the last 85 kyrs. Org. Geochem., 35, 347-354, doi: 10.1016/j.orggeochem.2003.10.011.

Sherrod, B. L., 1999: Gradient analysis of diatom assemblages in a Puget Sound salt marsh: Can such assemblages be used for quantitative paleoecological reconstruction? Palaeogeogr. Palaeoclimatol. Palaeoecol., 149, 213-226, doi: 10.1016/S0031-0182(98)00202-8.

Shiga, K. and I. Koizumi, 2000: Latest Quaternary oceanographic changes in the Okhotsk Sea based on diatom records. Mar. Micropaleontol., 38, 91-117, doi: 10.1016/ S0377-8398(99)00041-9.

Shimada, C. and S .Hasegawa, 2001: Paleoceanographic implications of a 90,000 year long diatom record in piston core KH94-3, LM-8 off NE Japan. Mar. Micropaleontol., 41, 153-166, doi: 10.1016/S0377-8398(00)00059-1.

Smith, W. O. and D. M. Nelson, 1985: Phytoplanton bloom produced by a receding ice edge in the Ross Sea: Spatial coherence with the density field. Science, 227, 163-166.

Stepanov, V. N., 1974: World Ocean. Znznie, Moscow, 256 pp.

Talley, L. D., 1991: An Okhotsk Sea water anomaly: Implications for ventilation in the North Pacific. Deep-Sea Res., 38, 171-190.

Ternois, Y., K. Kawamura, N. Ohkouchi, and L. D. Keigwin, 2000: Alkenone sea surface temperature in the Okhotsk Sea for the last $15 \mathrm{ka}$. Geochem. J., 34, 283-293.

Ternois, Y., K. Kawamura, L. D. Keigwin, N. Ohkouchi, and T. Nakatsuka, 2001: A biomarker approach for assessing marine and terrigenous inputs to the sediments of Sea of Okhotsk for the last 27,000 years. Geochim. Cosmochim. Acta., 65, 791-802, doi: 10.1016/S0016-7037(00)00598-6.

Wakabayashi, H., K. Hirano, F. Nishio, M. Aota, and S. Takahashi, 1995: A study of sea ice in the Sea of Okhotsk with SAR data. Polar Rec., 31, 305-314.

Watanabe, T. and M. Wakatsuchi, 1998: Formation of 26.8-26.9 $\sigma \theta$ water in the Kuril Basin of the Sea of Okhotsk as a possible origin of North Pacific Intermediate Water. $J$. Geophys. Res., 103, 2849-2865.

Wilson, D. L., W. O. Smith, and D. M. Nelson, 1986: Phytoplankton bloom dynamics of the western Ross Sea ice edge: Primary productivity and species-specific production. Deep-Sea Res., 33, 1375-1378.

Wong, C. S., R. J. Matear, H. J. Freeland, F. A. Whitney, and A. S. Bychkov, 1998: WOCE line P1W in the Sea of Okhotsk 2. CFCs and the formation rate of intermediate water. $J$. Geophys. Res., 103, 15625-15642.

Yasuda, I., 1997: The origin of the North Pacific Intermediate Water. J. Geophys. Res., 102, 893-909. 